"This document is the Accepted Manuscript version of a Published Work that appeared in final form in Inorganic Chemistry, copyright (c) American Chemical Society after peer review and technical editing by the publisher. To access the final edited and published work see DOI: 10.1021/acs.inorgchem.6bo1207."

\title{
Synthesis and antiproliferative activity of $\left[\mathrm{RuCp}\left(\mathrm{PPh}_{3}\right)_{2}(\mathrm{HdmoPTA})\right]\left(\mathrm{OSO}_{2} \mathrm{CF}_{3}\right)_{2} \quad\left(\mathrm{HdmoPTA}=3,7^{-\mathrm{H}-3,7^{-}}\right.$ dimethyl-1,3,7-triaza-5-phosphabicyclo[3.3.1] nonane)
}

Zenaida Mendoza, ${ }^{\dagger}$ Pablo Lorenzo-Luis, ${ }^{\dagger}$ Manuel Serrano-Ruiz, ${ }^{\ddagger}$ Elva Martín-Batista, ${ }^{\S}$ José M. Padrón, ${ }^{\S}$ Franco Scalambra ${ }^{\ddagger}$ and Antonio Romerosa ${ }^{*} \ddagger$

† Sección de Química Inorgánica, Departamento de Química, Facultad de Ciencias, Universidad de La Laguna, C/Astrofísico Francisco Sánchez 3, 38200, La Laguna, Tenerife, Spain

‡ Área de Química Inorgánica-CIESOL, Facultad de Ciencias, Universidad de Almería, Almería, Spain

§ BioLab, Instituto Universitario de Bio-Orgánica “Antonio González" (IUBO-AG), Centro de Investigaciones Biomédicas de Canarias (CIBICAN), Universidad de La Laguna, C/Astrofísico Francisco Sánchez 2, 38200 La Laguna, Tenerife, Spain

ABSTRACT: Complex $\left[\mathrm{RuCp}\left(\mathrm{PPh}_{3}\right)_{2}(\mathrm{HdmoPTA})\right]\left(\mathrm{OSO}_{2} \mathrm{CF}_{3}\right)_{2}$ (2) was synthesized and characterized by elemental analysis, IR and NMR spectroscopy. Its crystal structure was also determined by single-crystal X-ray diffraction. The complex showed a more potent antiproliferative activity than cisplatin against a representative panel of human cancer cells.

The development of effective anticancer drugs is mandatory for medicinal chemists. Cancer is one of the plagues of our time that has not a general and totally effective cure. The earliest studies by B. Rosenberg in 1965 on the antiproliferative activity of cisplatin and its FDA-approval as a chemotherapeutic agent in 1979 led to this compound to be one of the most clinical useful anticancer drugs. ${ }^{1}$ Nevertheless its value, cisplatin is not active against all cancer forms and displays several undesirable side effects such as large toxicity. ${ }^{2}$ Many attempts are being focused to obtain new valuable anticancer drugs, effective on a large classes of cancer varieties, less toxic and better tolerated by the human body. Some compounds containing metals different to Pt have showed comparable anticancer activity than cisplatin but with fewer side effects, ruthenium complexes being one of the most currently interesting alternative. ${ }^{3}$ Regarding platinum compounds ruthenium complexes exhibit lower systemic toxicity and specific accumulation in cancer cells. ${ }^{3,6}$ The early experiments (1980s) with fac- $\left[\mathrm{Cl}_{3}\left(\mathrm{NH}_{3}\right)_{3} \mathrm{Ru}\right]$, cis- $\left[\mathrm{Cl}_{2}\left(\mathrm{NH}_{3}\right)_{4} \mathrm{Ru}\right] \mathrm{Cl}$ (CCR) and (ImH)trans$\left[(\mathrm{Im})_{2} \mathrm{Cl}_{4} \mathrm{Ru}\right]$ (ICR) showed that these compounds are active agents against the cervix cancer cell line HeLa with less toxicity than cisplatin. ${ }^{4}$ Since these initial findings, new anticancer ruthenium-based therapeutic agents such as NAMI-A, KP1019, NKP1339, KP418 or RAPTA derivatives (Figure 1) have been obtained. ${ }^{3,5}$
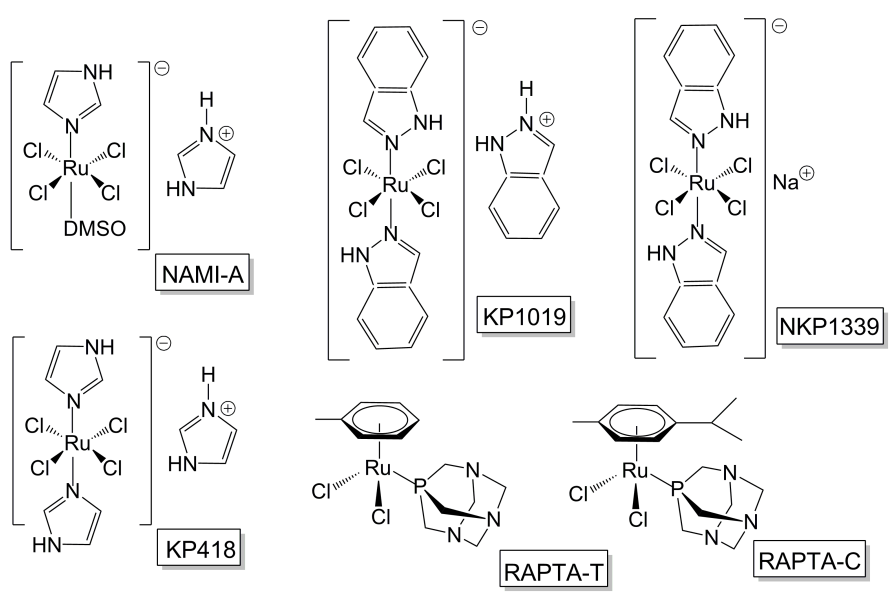

Figure 1. Some known ruthenium complexes with significant anticancer and antimetastatic activity.

In the past, we have been engaged actively in the synthesis of arene-ruthenium complexes $\left[\mathrm{RuCpX}(\mathrm{L})\left(\mathrm{L}^{\prime}\right)\right]^{\mathrm{n}+}\left(\mathrm{X}=\mathrm{Cl} ; \mathrm{L} \mathrm{PPh}_{3} ; \mathrm{L}^{\prime}\right.$ = PTA, mPTA) $($ PTA = 1,3,5-triaza-7-phosphaadamantane; mPTA $=N$-methyl-PTA) (Figure 2), which showed good water solubility and active cytotoxic properties particularly on cisplatin resistant cells. $^{7}$ Their antiproliferative activities were related to ligands bonded to the metal, which modify the electronic properties of the complexes but also their partition coefficient $(\log P)$. The outcome of those studies pointed out that the same basic structure with new PTA derivatives (Figure 2) could provide more active anticancer agents. 

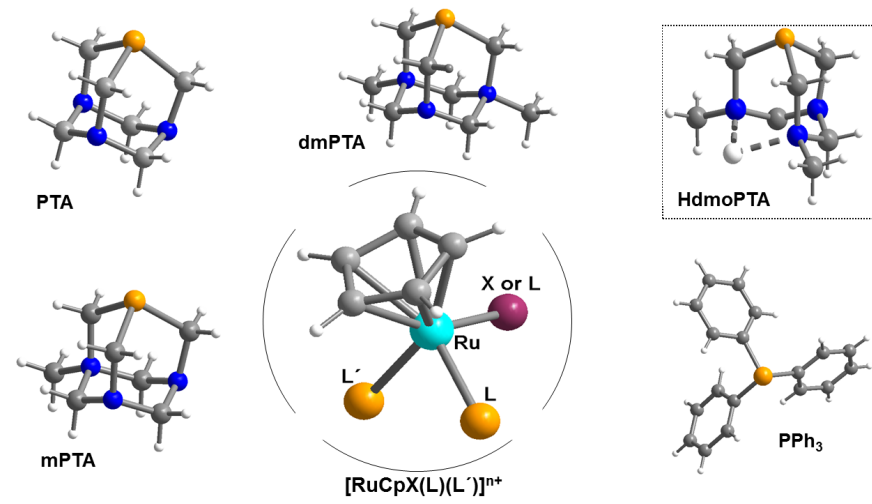

Figure 2. A careful selection of ligands, metal centre, and reaction conditions can confer control over the topology of the piano-stool complexes $\left[\operatorname{RuCpX}(\mathrm{L})\left(\mathrm{L}^{\prime}\right)\right]^{\mathrm{n}+}(\mathrm{X}$ $=\mathrm{Cl} ; \mathrm{L}=\mathrm{PPh}_{3} ; \mathrm{L}^{\prime}=\mathrm{PTA}, \mathrm{mPTA} ;$ dmPTA$;$ HdmoPTA) allowing modulation of the activity against human tumour cells.

With this aim, the ruthenium complex $\left[\mathrm{RuClCp}\left(\mathrm{PPh}_{3}\right)(\mathrm{HdmoPTA})\right]\left(\mathrm{OSO}_{2} \mathrm{CF}_{3}\right) \quad(\mathbf{1})$, containing the new PTA derivative 3,7-H-3,7-dimethyl-1,3,7-triaza-5phosphabicyclo[3.3.1]nonane (HdmoPTA), was obtained. ${ }^{8}$ This ligand is able to be solubilized in water and organic solvents and its solubility could be modified easily by deprotonation.

Complex 1 was identified as an antiproliferative compound against a panel of representative human solid tumor cell lines with $\mathrm{GI}_{50}$ values in the range 1.5-2.6 $\mu \mathrm{M}$ (Table 1, vide infra). Nevertheless, it is important to stress that the antiproliferative properties of this complex were found to be clearly different to those of their parent complexes. ${ }^{9}$

Substitution of the proton in HdmoPTA by a metal provided bis-heterometal complexes $\quad\left[\mathrm{RuClCp}\left(\mathrm{PPh}_{3}\right)\right.$ - $\mu$-dmoPTA$\left.1 \kappa P: 2 \kappa^{2} N, N^{\prime}-\mathrm{MCl}_{2}\right](\mathrm{M}=\mathrm{Co}, \mathrm{Ni}, \mathrm{Zn}),{ }^{10 a}$ which showed similar antiproliferative activity than $1 .^{9}$ This fact suggested that the biological activity of these complexes could implicate the exchange of the $\mathrm{Cl}$ bonded to the $\mathrm{Ru}$, as for Pt complexes has been observed. ${ }^{4}$ To investigate this possibility the new $\{\mathrm{CpRu}\}$ parent complex $\left[\mathrm{RuCp}\left(\mathrm{PPh}_{3}\right)_{2}(\mathrm{HdmoPTA})\right]\left(\mathrm{OSO}_{2} \mathrm{CF}_{3}\right)_{2}(\mathbf{2})$, which does not contain $\mathrm{Cl}$ bonded to the metal, was synthesized (see $\mathbf{E S I}^{\dagger}$ ) by the reaction of $\left[\mathrm{RuClCp}\left(\mathrm{PPh}_{3}\right)_{2}\right]$ first with $\mathrm{Ag}\left(\mathrm{OSO}_{2} \mathrm{CF}_{3}\right)$ and then with $\operatorname{dmPTA}\left(\mathrm{OSO}_{2} \mathrm{CF}_{3}\right)_{2}$ (Scheme 1) $\left(\mathrm{dmPTA}=N, N^{\prime}\right.$-dimethylPTA; Figure 2). ${ }^{8}$

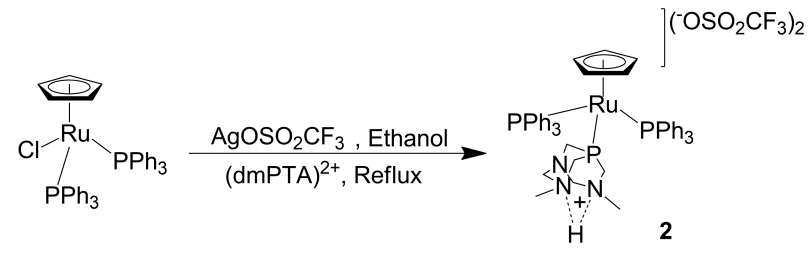

Scheme 1. Synthesis of $\left[\mathrm{RuCp}\left(\mathrm{PPh}_{3}\right)_{2}(\mathrm{HdmoPTA})\right]\left(\mathrm{OSO}_{2} \mathrm{CF}_{3}\right)_{2}(\mathbf{2})$

Complex $\mathbf{2}$ is soluble in organic solvents such as chloroform, acetone, methanol, DMSO and mostly insoluble in water $\left(\mathrm{S}_{25, \mathrm{H}_{2} \mathrm{O}}\left(\mathrm{mg} / \mathrm{cm}^{3}\right): 0.2\right)$. The complex remains unaltered in DMSO and $\mathrm{DMSO} / \mathrm{H}_{2} \mathrm{O}$ solutions under air for more than $2 \mathrm{~h}$ both at room temperature and $38{ }^{\circ} \mathrm{C}$. Its ${ }^{1} \mathrm{H}$ NMR $\left(\mathrm{CDCl}_{3}\right)$ displays a characteristic $\eta^{5}$-Cp singlet at $4.90 \mathrm{ppm}$, which is shifted to low field with respect to its correspondent in $1(4.56 \mathrm{ppm})$ in acetone- $\mathrm{d}_{6}$. The $\mathrm{PPh}_{3}$ signals $(30 \mathrm{H})$ arise at typical aromatic range. The remaining signals belong to the HdmoPTA group, two contiguous broad singlets are due to both $\mathrm{NCH}_{3}$ groups at $2.35 \mathrm{ppm}$ and 2.36 ppm $(6 \mathrm{H})$, which resemble those of the $\mathrm{NCH}_{3}$ groups in $\mathbf{1}$ (2.49 ppm). ${ }^{8}$ Finally, the multiplet at $1.25 \mathrm{ppm}(1 \mathrm{H})$ corresponds to the hydrogen shared between both $\mathrm{N}_{\mathrm{CH}_{3}}$ atoms. This suspicion was confirmed by a ${ }^{1} \mathrm{H},{ }^{1} \mathrm{H}-2 \mathrm{D}$ COSY NMR experiment that showed how this signal is coupled with $\mathrm{NCH}_{2} \mathrm{NCH}_{3}$ and $\mathrm{PCH}_{2} \mathrm{NCH}_{3}$ groups (Figure $\mathbf{S} \mathbf{1}, \mathbf{E S I}^{\dagger}$ ). The ${ }^{31} \mathrm{P}\left\{{ }^{1} \mathrm{H}\right\} \mathrm{NMR}$ in $\mathrm{CDCl}_{3}$ shows a doublet at $38.44 \mathrm{ppm}\left({ }_{2} \mathrm{P}\right)$ and a triplet at $-13.94 \mathrm{ppm}\left({ }_{1} \mathrm{P}\right)$ that only could be assigned respectively to two $\mathrm{PPh}_{3}$ and one HdmoPTA coordinated by the $\mathrm{P}$ atom despite of those chemical shifts are quite different to those in complex 1 (46.13 ppm; -1.8o ppm) in acetone- $\mathrm{d}_{6}$.

The crystal structure of $\mathbf{2}$ was determined by single-crystal Xray diffraction and is showed in Figure 3 (selected crystallographic parameters, distances and angles are display in Table S1, ESI ${ }^{\dagger}$ ). The crystallographic study confirmed that the coordination sphere of the $\mathrm{Ru}$ is a distorted pseudo-octahedron constituted by a $\eta^{5}-\mathrm{Cp}$, two $\mathrm{PPh}_{3}$ and a HdmoPTA bonded by the $\mathrm{P}$ atom. The $C p$ ring is essentially planar (the larger separation from the overall Cp plane is o.0o89 $\AA(\mathrm{C} 84)$ ), being the distance to the metal ( $\mathrm{Ru}-\mathrm{Cp}_{\text {cent. }}=1.886 \AA$ ) similar to those found in parent $\mathrm{Cp}$-pianostool complexes. ${ }^{8,10}$ The angle between the $\mathrm{Cp}$ plane and the plane defined by $\mathrm{P}_{1}-\mathrm{Ru}_{1}-\mathrm{P}_{3}\left(47.6^{\circ}\right)$ and $\mathrm{P}_{2}-\mathrm{Ru}_{1}-\mathrm{P}_{3}\left(46.8^{\circ}\right)$ are smaller than that in $\mathbf{1}\left(55.3^{\circ}\right)$ while the angle $\mathrm{P}_{1}-\mathrm{Ru}_{1}-\mathrm{P}_{2}$ is found to be $103.3(4)^{\circ}$, which is near to that observed in similar complexes $\left.\left[\mathrm{RuCpX}\left(\mathrm{PPh}_{3}\right)_{2}\right]\left(\mathrm{X}=\mathrm{CN}, 103.6(1)^{\circ} ; \mathrm{CNHCN}, 102.5(1)^{\circ}\right)\right)^{11}$ The $\mathrm{N}_{\mathrm{CH}_{3}} \cdots \mathrm{N}_{\mathrm{CH}_{3}}$ distance of $2.800 \AA$ is somewhat larger than that for 1 $\left(\mathrm{d}_{\mathrm{N}_{1} \mathrm{P} \cdots \mathrm{N}_{3} \mathrm{P}}=2.702 \AA\right)$ and the torsion angles for the cationic unit HdmoPTA $\left(\mathrm{C}_{75}-\mathrm{N}_{73}-\mathrm{C}_{73}-\mathrm{P}_{3}=-57.3^{\circ}\right.$ and $\left.\mathrm{C}_{76}-\mathrm{N}_{71}-\mathrm{C}_{71}-\mathrm{P}_{3}=51.6^{\circ}\right)$ somewhat shorter than those in $1\left(\mathrm{C}_{5} \mathrm{P}-\mathrm{N}_{1} \mathrm{P}-\mathrm{C}_{3} \mathrm{P}-\mathrm{P}_{2}=-54.5^{\circ}\right.$ and $\left.\mathrm{C}_{4} \mathrm{P}-\mathrm{N}_{3} \mathrm{P}-\mathrm{C}_{1} \mathrm{P}-\mathrm{P}_{2}=5^{8} \cdot 9^{\circ}\right) .{ }^{8}$

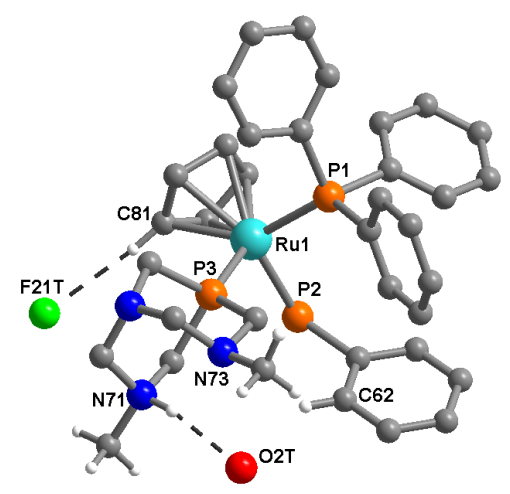

Figure 3. A perspective drawing of 2 with atom numbering. For the sake of clarity, the dashed lines $\mathrm{N}_{73} \cdots \mathrm{H}_{71}(2.178(4) \AA)$ and O2T $\cdots \mathrm{H}_{62}(2.578(4)$ Å were omitted.

Furthermore, the $\mathrm{O}_{2} \mathrm{~T}$ is located more than $3 \AA$ from C62, well outside of normal H-bonding distance but at 2.814(6) Å from N71, bond length that supports the $\mathrm{H}$-bond interaction $\mathrm{N}_{71}-\mathrm{H}_{71} \cdots \mathrm{O}_{2} \mathrm{~T}$ $\left(\mathrm{d}_{\mathrm{H}_{71} \cdots \mathrm{O}_{2} \mathrm{~T}}=2.103(4) \AA\right)$. Likewise, the crystal packing diagram is strengthened by another weak intermolecular interaction (C81$\mathrm{H} 81 \cdots \mathrm{F}_{21}=3.433(3) \AA$ ) and the $\mathrm{C}-\mathrm{H} / \pi$ interactions $^{12}$ between the aromatic centroid and the adjacent phenyl-C-H groups (centroidto-C-H distances from 3.183(5) to 4.039(5) Å, Figure 4). 


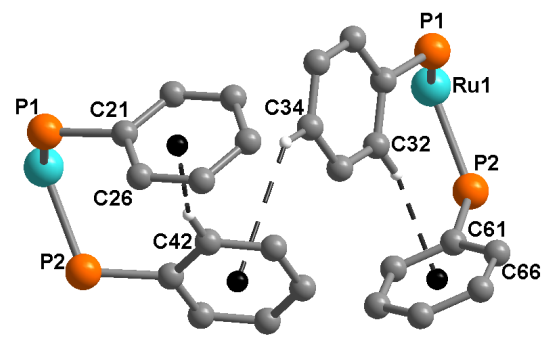

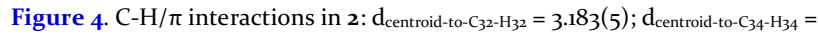

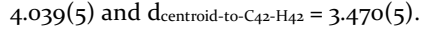

The antiproliferative activity of $\mathbf{2}$ was studied in a panel of representative human solid tumour cell lines. ${ }^{13}$ Thus, cells were exposed to the compound for $48 \mathrm{~h}$ and the results expressed as $\mathrm{GI}_{50}$ are given in Table 1. Overall, the $\mathrm{GI}_{50}$ values of $\mathbf{2}$ against all cell lines were in the range $0.17-0.29 \mu \mathrm{M}$, which are significantly lower than those for the reference anticancer drug cisplatin and complex 1. Significant differences between antiproliferative activity of 2 and cisplatin were observed for T-47D (ca. 70:1) and WiDr (> 100:1) cells, which are more cisplatin resistant. ${ }^{9}$

It is important to point out that the $\mathrm{GI}_{50}$ values of $\mathbf{2}$ are larger than those for 1. ${ }^{9}$ To the best of our knowledge the antiproliferative activity of $\mathbf{2}$ against human solid tumour cell lines is among the largest known. ${ }^{14}$

The main structural difference between $\mathbf{1}$ and $\mathbf{2}$ is the presence of one or two $\mathrm{PPh}_{3}$ groups, respectively. The enhancement of the biological activity due to the addition of $\mathrm{PPh}_{3}$ ligands has been reported for other ruthenium complexes. ${ }^{15}$ This result is consistent with the reported findings for $\mathbf{1}$ and 2, and with our previous observations of the parent PTA and HPTA complexes $\left.\mathrm{RuCp}(\mathrm{DMSO}-\kappa \mathrm{S})(\mathrm{PTA})_{2}\right]\left(\mathrm{OSO}_{2} \mathrm{CF}_{3}\right), \quad$ [RuCp(DMSO$\left.\kappa \mathrm{S})(\mathrm{HPTA})_{2}\right] \mathrm{Cl}_{3} \cdot 2 \mathrm{H}_{2} \mathrm{O}$ and $\left[\mathrm{RuClCp}(\mathrm{HPTA})_{2}\right] \mathrm{Cl}_{2} \cdot 2 \mathrm{H}_{2} \mathrm{O},{ }^{10 b}$ which were tested against HeLa, SW1573, T-47D and WiDr cells, resulting inactive ( $\mathrm{GI}_{50}>100 \mu \mathrm{M}$ ) in all cell lines (unpublished results). Noteworthy, the presence of $\mathrm{PPh}_{3}$ groups is not always enough for ensuring an antiproliferative effect. Solubility of the complexes plays also a crucial role. For instance, $\{\mathrm{CpRu}\}$ precursor $\left[\mathrm{RuClCp}\left(\mathrm{PPh}_{3}\right)_{2}\right]$ is insoluble under the NCI protocol requirements (40 mM in DMSO) and therefore could not be tested. ${ }^{13}$

Table 1. $\mathrm{GI}_{50}$ values of complexes $\mathbf{1},{ }^{\mathrm{a}} \mathbf{2}$ and cisplatin against human solid tumor cells lines.

\begin{tabular}{cccccc}
\hline & \multicolumn{5}{c}{ Cell line (origin) } \\
\cline { 2 - 6 } & $\begin{array}{c}\text { A549 } \\
(\text { lung) }\end{array}$ & HeLa & SW1573 & T-47D & WiDr \\
& - & 2.6 & 1.5 & 1.9 & 1.7 \\
\hline $1^{\mathrm{a}}$ & & $( \pm 0.2)$ & $( \pm 0.1)$ & $( \pm 0.5)$ & $( \pm 0.4)$ \\
& 0.29 & 0.17 & 0.20 & 0.25 & 0.20 \\
\multirow{2}{*}{2} & $( \pm 0.09)$ & $( \pm 0.04)$ & $( \pm 0.02)$ & $( \pm 0.04)$ & $( \pm 0.03)$ \\
& 4.9 & 1.8 & 2.7 & 17 & 23 \\
& $( \pm 0.2)$ & $( \pm 0.5)$ & $( \pm 0.4)$ & $( \pm 3.3)$ & $( \pm 4.3)$ \\
\hline
\end{tabular}

a $\left[\mathrm{RuClCp}\left(\mathrm{PPh}_{3}\right)(\mathrm{HdmoPTA})\right]\left(\mathrm{OSO}_{2} \mathrm{CF}_{3}\right)(\mathbf{1}) \mathbf{9}$

${ }^{b}$ Values are given in $\mu \mathrm{M}$ and are means of at least three experiments ( \pm standard deviation).

Next, we examined cell cycle phase distribution by flow cytome$\operatorname{try}^{13}$ to determine whether cell growth inhibition caused by compound 2 involved cell cycle changes (Figure 5, Table S6, ESI ${ }^{\dagger}$ ). Contrary to cisplatin, which induces the accumulation in S-phase of A549, SW1573 and WiDr cells, we found that ruthenium com- plex 2 produced the accumulation at G1 phase of the cell cycle. However, in HeLa cells, cisplatin is known to induce accumulation at G1 phase. ${ }^{16}$ Interestingly, compound 2 produced an increase of the G2/M compartment in HeLa. These results clearly indicate that the mechanism of action of the new compound differs from that of cisplatin.

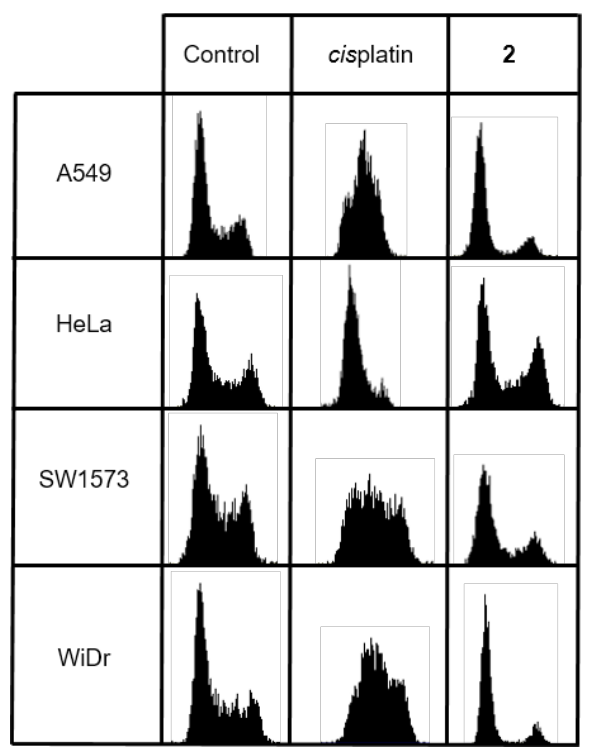

Figure 5. Histogram of untreated cells (C) and cells treated (drug dose in $\mu \mathrm{M}$ ) for $24 \mathrm{~h}$ with cisplatin (CDDP) and complex 2. Cells were exposed to cisplatin at $10 \mu \mathrm{M}$ (A549, HeLa and SW1573) or $20 \mu \mathrm{M}$ (WiDr), and to complex 2 at $0.5 \mu \mathrm{M}$.

H. Liu and P. Sadler ${ }^{17}$ have shown that the insertion of a coordinated aromatic ligand able to intercalate into DNA provides some metal complexes with a dual mode of binding, that is, intercalation between the DNA bases and metal coordination to a DNA base. Ru-arene complexes with such a dual mode of binding exhibit stronger cytotoxicity toward cancer cells than the nonintercalating counterparts. ${ }^{18}$

Cell cycle experiments together with our previous finding for complex $1,{ }^{9}$ allow us to discard DNA as the main biological target for compound $\mathbf{2}$. It has been described that ruthenium compounds might directly interfere with proteins. ${ }^{\mathbf{4} \mathbf{b}}$ At present, this extent has not been confirmed for complex 2.

Another interesting point to study is the role of the positively charged complex, which might be essential to force interaction with the negatively charged cell membrane. The geometries of complexes 1 and 2 were modelled by DFT ${ }^{19,20}$ (see $\mathbf{E S I}^{\dagger}$ ) with the aim of obtaining information of how it changes from those in crystal and to know how the charges are distributed in molecules, which could justify their different antiproliferative activity. The modelled structures of both complexes retain the disposition of the ligands around the metal as in the crystal. The HOMOLUMO energy gap is very similar in both complexes $(3.840 \mathrm{eV}$ for 1, $3.858 \mathrm{eV}$ for 2), being the HOMO/LUMO energies of $\mathbf{1}$ the higher $(\mathbf{1}$ : $\mathrm{HOMO}=-\mathbf{1 0} .267 \mathrm{eV}, \mathrm{LUMO}=-6.427 \mathrm{eV} ; \mathbf{2}: \mathrm{HOMO}=-$ $7.333 \mathrm{eV}, \mathrm{LUMO}=-3.475 \mathrm{eV}$ ). For both complexes the largest bond distance differences respecting those in crystal structures were found for Ru-P bonds: $+8.7 \%$ for Ru1-P1 in 1 and $+10.5 \%$ for Ru1-P2 in 2. 
The charge distribution on the phenyl rings of 1 and 2 do not differ significantly. Therefore, the electronic distribution in both complexes is similar and could not justify the large antiproliferative activity differences between them. Nevertheless, the separation (from 3.951 to $3.871 \AA$ ) between both almost parallel $\left(4.73^{\circ}\right.$, Figure $\mathbf{S}_{4}, \mathbf{E S I}^{\dagger}$ ) phenyl rings $\mathrm{C}_{21}-\mathrm{C}_{2} 6$ and C61-C66 (Figure 4), which could be the responsible of the exceptional antiproliferative activity of $\mathbf{2}^{21}$ Nonetheless, other possible mechanisms have been identified to justify the biological activity of ruthenium complexes $^{14}$ and therefore, further studies outside the scope of this work will be necessary to depict the mechanism of action of 2.

In conclusion, complex $\mathbf{2}$ displays a high antiproliferative activity largely bigger than most of the known platinum drugs and ruthenium complexes. Experimental and theoretical studies are in progress to determine the specific mechanism of action of complex 2 against cancer cells. The synthesis of parent ruthenium complexes containing the ligand HdmoPTA and its derivatives is also in progress as well as the study of their biological activity.

\section{ASSOCIATED CONTENT}

\section{Supporting Information}

The Supporting Information $\mathbf{E S I}^{\dagger}$ is available free of charge on the ACS Publications website at DOI:

Experimental procedures, NMR spectroscopic data and Figure S1 giving ${ }^{1} \mathrm{H},{ }^{1} \mathrm{H}-2 \mathrm{D}$ COSY NMR of 2; Growth inhibition assays of compound 2, Table $\mathrm{S}_{1}$ giving selected X-ray crystallographic data of compound 2; Tables $\mathrm{S}_{2}-\mathrm{S}_{5}$ and Figures $\mathrm{S}_{2}$ and $\mathrm{S}_{3}$ giving the DFT details for complexes 1 and 2, respectively and Figure $\mathrm{S}_{4}$ giving optimized structure of $\mathbf{2}$ including planes containing the aryls $\mathrm{C}_{21}-\mathrm{C}_{2} 6$ and $\mathrm{C61-C66}$, angle between them and separation between rings and facing planes (PDF); Table S6 summarize the histograma of human solid tumour cells after exposure to compounds for $24 \mathrm{~h}$.

X-ray crystallographic data of complex 2 (CCDC 1465060) (CIF).

\section{AUTHOR INFORMATION}

\section{Corresponding Author}

"Email: romerosa@ual.es

\section{Author Contributions}

The manuscript was written through contributions of all authors. All authors have given approval to the final version of the manuscript.

\section{Notes}

The authors declare no competing financial interests.

\section{ACKNOWLEDGMENT}

Thanks are given to the European Commission FEDER program for co-financing the projects CTQ2015-67384-R (MINECO) and Po9-FQM-5402 (Junta de Andalucía). Thanks are also given to Junta de Andalucía PAI-research group FQM-317 and COST Action $\mathrm{CM}_{1302}\left(\mathrm{WG}_{1}, \mathrm{WG}_{2}\right.$ ). M. S.-R. is grateful to Excellence project Po9-FQM-5402 for a postdoctoral contract and F. S. to University of Almeria for a predoctoral grant. J. M. P. thanks the EU Research Potential (FP7-REGPOT- 2012-CT2012- 31637-IMBRAIN).
(1) Wheate, N. J.; Walker, S.; Craig, G. E.; Oun, R. Dalton Trans. 2010, 39, 8113-8127.

(2) Wang, X.; Guo, Z. Chem. Soc. Rev. 2013, 42, 202224.

(3) Spreckelmeyer, S.; Orvig, C.; Casini, A. Molecules 2014, 19, 15584-15610.

(4) Clarke, M. J. Coord. Chem. Rev. 2002, 232, 69-93.

(5) (a) Ang, W.H.; Daldini, E.; Scolaro, C.; Scopelliti, R.; Juillerat-Jeannerat, L.; Dyson, P. J. Inorg. Chem. 2006, 45, 9006-9013. (b) Gasser, G.; Ott, I.; Nolte, N.M. J. Med. Chem. 2011, 54, 3-25. (c) Hartinger, C. G.; Zorbas-Seifried, S.; Jakupec, M. A.; Kynast, B.; Zorbas, H.; Keppler, B. K. J. Inorg. Biochem. 2006, 100, 891-904. (d) Zaki, M.; Arjmand, F.; Tabassum, S. Inorg. Chim. Acta, 2016, 444, 1-22.

(6) (a) Allardyce, C. S.; Dorcier, A.; Scolaro, C.; Dyson, P. J. Appl. Organometal. Chem. 2005, 19, 1-10. (b) Santamaría, R.; Irace, C.; Érrico, G. D.; Montesarchio, D.; Paduano, L. J. Pharm. Drug Devel. 2003, 1(2), e201.

(7) (a) Akbayeva, D. N.; Gonslavi, L.; Oberhauser, W.; Peruzzini, M.; Vizza, F.; Brüggeller, P.; Romerosa, A.; Sava, G.; Bergamo, A. Chem. Commun. 2003, 264- 265. (b) Romerosa, A.; Campos-Malpartida, T.; Lidrissi, C.; Saoud, M.; Serrano-Ruiz, M.; GarridoCárdenas, J. A.; García-Moroto, F. Inorg. Chem. 2006, 45, 1289-1298.

(8) Mena-Cruz, A.; Lorenzo-Luis, P.; Romerosa, A.; Saoud, M.; Serrano-Ruiz, M. Inorg. Chem. 2007, $46,6120-6128$.

(9) Ríos-Luci, C.; León, L. G.; Mena-Cruz, A.; PérezRoth, E.; Lorenzo-Luis, P.; Romerosa, A.; Padrón, J. M. Bioorg. Med. Chem. Lett. 2011, 21, 4568-4571.

(10)(a) Serrano-Ruiz, M.; Aguilera-Sáez, L.M.; LorenzoLuis, P.; Padrón, J. M.; Romerosa, A. Dalton Trans. 2013, 42, 11212-11219; (b) Serrano-Ruiz, LorenzoLuis, P.; Romerosa, A; Mena-Cruz A. Dalton Trans. 2013, 42, 7622-7630.

(11)Sapunov, V. N.; Mereiter, K.; Schmid, R.; Kirchner, K. J. Organomet. Chem. 1997, 530, 105-115.

(12)Meyer, E. A.; Castellano, R. K.; Diederich, F. Angew. Chem. Int. Ed. 2003, 42, 1210-1250.

(13)Nieto, D.; Bruña, S.; González-Vadillo, A. M.; Perles, J.; Carrillo-Hermosilla, F.; Antiñolo, A.; Padrón, J. M.; Plata, G. B.; Cuadrado, I. Organometallics 2015, 34, 5407-5417.

(14)(a) Wani, W. A.; Prashar, S.; Shreaz, S.; GómezRuiz, S. Coord. Chem. Rev. 2016, 312, 67-98. (b) Furrer, J.; Süss-Fink, G. Coord. Chem. Rev. 2016, 309, 36-50. (c) Singha, S. K.; Pandey, D. S. RSC Adv. 2014, 4, 1819-1840. (d) Côrte-Real, L.; Robalo, M. P.; Marques, F.; Nogueira, G.; Avecilla, F. J. Inorg. Biochem. 2015, 150, 148-159. (e) Völker, T.; Meggers, E. Curr. Opin. Chem. Biol. 2015, 25, 48-54. (f) Martin, E. K.; Pagano, N.; Sherlock, M. E.; Harms, K.; Meggers, E. Inorg. Chim. Acta 2014, 423, 530-539.

(15)(a) Côrte-Real, L.; Robalo, M. P.; Marques, F.; Nogueira, G.; Avecilla, F.; Silva, T. J. L.; Santos, F. C.; Tomaz, A. I.; Garcia, M. H.; Valente, A. J. Inorg. Biochem. 2015, 150, 148-159. (b) Sáez, R.; Lorenzo, J.; Prieto, M. J.; Font-Bardia, M.; Calvet, T.; Omeñaca, N.; Vilaseca, M.; Moreno, V. J. Inorg. Biochem. 2014, 136, 1-12.

(16)Larasati, Y. A.; Putri, D. D. P.; Utomo, R. Y.; Hermawan, A.; Meiyanto, E. J. Appl. Pharm. Sci. 2014, 4, 14-19. 
(17)Liu, Hong-Ke; Sadler, P. J. Acc. Chem. Res. 2011, 44, 349-359.

(18)Bugarcic, T.; Nováková, O.; Halámiková, A.; Zerzánková, L.; Vrána, O.; Kašpárková, J.; Habtemariam, A.; Parsons, S.; Sadler, P. J.; Brabec, v. J. Med. Chem. 2008, 51, 5310-5319.

(19)(a) Szabo A.; Ostlund, N. S. Modern quantum chemistry, Dover Publications Inc., Mineola, New York, 1996; (b) Becke, A. D. J. Chem. Phys. 1993, 98, 1372-1377. (c) Lee, C.; Yang, W.; Parr, R. G. Phys. Rev. $B, 1988,37,785-789$.

(20)Valiev, M.; Bylaskaa, E. J.; Govind, N.; Kowalski, K.; Straatsma, T. P.; Van Dam, H. J. J.; Wang, D.; Nieplocha, J.; Apra, E.; Windus, T. L.; de Jong, W. A. Comput. Phys. Comm. 2010, 181, 1477-1489. (21)(a) Hall, J. P.; Sanchez-Weatherby, J.; Alberti, C.; Quimper, C. H.; O'Sullivan, K.; Brazier, J. A.; Winter, G.; Sorensen, T.; Kelly, J. M.; Cardin, D. J.; Cardin, C. J. J. Am. Chem. Soc. 2014, 136, 17505-17512. (b) Hall, J. P.; Beer, H.; Buchner, K.; Cardin, D. J.; Cardin, C. J. Organometallics, 2015, 34, 2481-2486. 


\section{Synthesis and antiproliferative activity of $\left[\mathrm{RuCp}\left(\mathrm{PPh}_{3}\right)_{2}(\mathrm{HdmoPTA})\right]\left(\mathrm{OSO}_{2} \mathrm{CF}_{3}\right)_{2} \quad\left(\mathrm{HdmoPTA}=3,7^{-\mathrm{H}-3,7^{-}}\right.$ dimethyl-1,3,7-triaza-5-phosphabicyclo[3.3.1] nonane).}

Zenaida Mendoza, ${ }^{\dagger}$ Pablo Lorenzo-Luis, ${ }^{\dagger}$ Manuel Serrano-Ruiz, ${ }^{\ddagger}$ Elva Martín-Batista, ${ }^{\S}$ José M. Padrón, ${ }^{\S}$ Franco Scalambra ${ }^{\ddagger}$ and Antonio Romerosa ${ }^{* \neq}$

The complex $\left[\mathrm{RuCp}\left(\mathrm{PPh}_{3}\right)_{2}(\mathrm{HdmoPTA})\right]\left(\mathrm{OSO}_{2} \mathrm{CF}_{3}\right)_{2}$ showed more potent antiproliferative activity than cisplatin against a representative panel of human cancer cells.

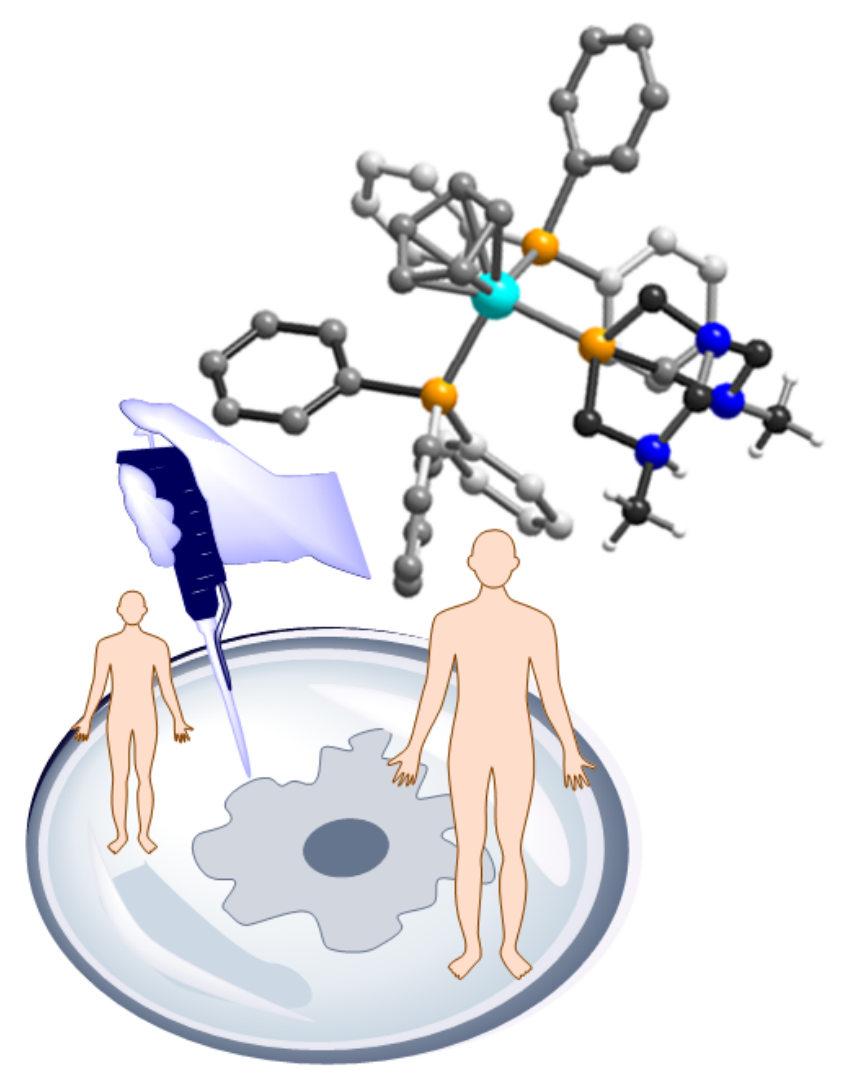

